\title{
Allogeneic cell therapy bioprocess economics and optimization: downstream processing decisions
}

\begin{abstract}
Aim: To develop a decisional tool to identify the most cost-effective process flowsheets for allogeneic cell therapies across a range of production scales. Materials \& methods: A bioprocess economics and optimization tool was built to assess competing cell expansion and downstream processing (DSP) technologies. Results: Tangential flow filtration was generally more cost effective for the lower cells/lot achieved in planar technologies and fluidized bed centrifugation became the only feasible option for handling large bioreactor outputs. DSP bottlenecks were observed at large commercial lot sizes requiring multiple large bioreactors. The DSP contribution to the cost of goods/dose ranged between $20-55 \%$, and $50-80 \%$ for planar and bioreactor flowsheets, respectively. Conclusion: This analysis can facilitate early decision-making during process development.
\end{abstract}

Keywords: allogeneic cell therapy manufacture $\bullet$ bioprocess economics $\bullet$ centrifugation - downstream processing • filling • tangential flow filtration

Allogeneic stem cells are showing clinical promise in several therapeutic indications, with regional approvals for graft-versus-host disease (GvHD; Prochymal ${ }^{\circledR}$, Osiris) and osteoarthritis (Cartistem ${ }^{\circledR}$, Medipost). Advantages of allogeneic cell therapies include being sourced from a healthy donor, which makes it more possible to scale-up rather than scale-out and cryopreserve the cell-based product for short-term storage and multidosing [1]. Hence it is possible to envisage allogeneic therapies following a product-driven, off-the-shelf business model. Yet, several cell therapy products have experienced manufacturing challenges upon scale-up leading to processes with high cost of goods (COG) and high process variability [2-4]. This has triggered increasing interest in estimating manufacturing costs and identifying opportunities for cost reduction. Simaria $e t$ al. present a detailed process economics analysis for cell expansion that predicted dose-demand combinations when planar technologies would cease to be feasible, as well as target performance capabilities of microcarrier-based systems for the industry to be sustainable for high-demand, high-dose $\left(10^{9}\right.$ cells/dose) scenarios [5]. The commercial feasibility of cell therapies for large commercial lot sizes (e.g., $10^{12}$ cells/lot) will depend not only on the technology capabilities for expansion but also on commercially available technologies for downstream processing that are capable of handling this high cell load. This article presents a decisional tool to investigate the impact of commercial doses, demands and lot sizes on the cost-effectiveness of scalable, single-use downstream processing and fill finish technologies for cell therapies.

Figure 1 illustrates a typical cell therapy process flowsheet for allogeneic cell therapies. Cell expansion is performed using either planar technologies such as T-flasks or multi-layer stacked vessels (e.g., Cell Factories [Nunc, ThermoFischer Scientific, MA, USA], Cell-STACKs or HYPERstacks [Corning Incorporated Life Sciences, MA, USA]) or via 3D microcarrier-based culture in single-use bioreactors. Following enzymatic treatment (e.g., trypsinization) to release the adherent cells, the downstream processing
Sally Hassan', Ana S Simaria', Hemanthram Varadaraju ${ }^{2,3}$, Siddharth Gupta ${ }^{2}$, Kim Warren $^{2}$ \& Suzanne S Farid*,1 'The Advanced Centre for Biochemical Engineering, Department of Biochemical Engineering, University College London, Gordon Street, London, WC1H OAH, UK ${ }^{2}$ Development Services, Cell Therapy، Lonza Walkersville, Inc., 8830 Biggs Ford Road, US - 21793-0127 Walkersville, MD, USA

${ }^{3}$ Modern Meadow, 140 58th Street Building A, Suite 8J Brooklyn, NY 11220, USA

*Author for correspondence: Tel.: +44 (0) 2076794415 Fax: +44 (0) 2079163943 s.farid@ucl.ac.uk 


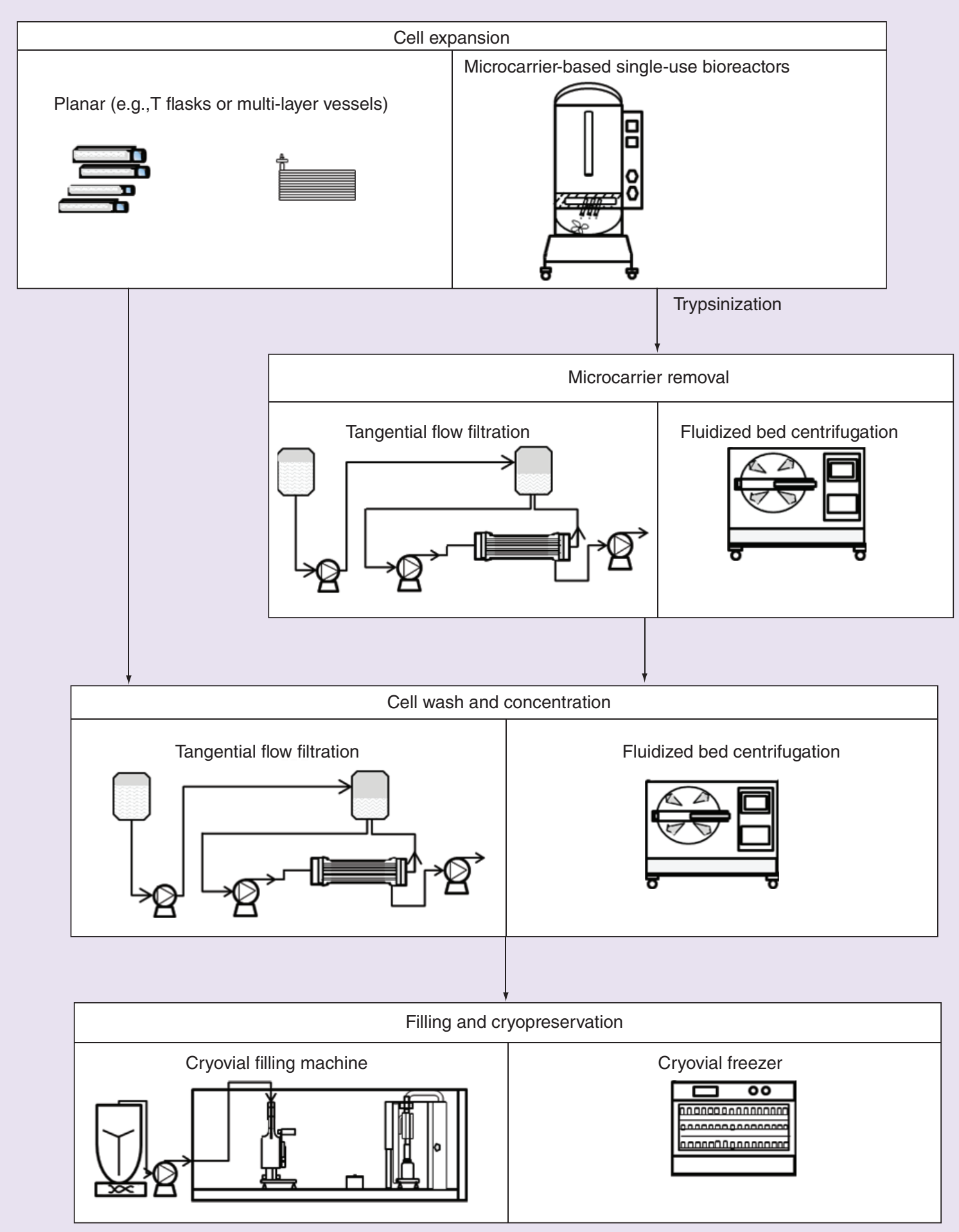

Figure 1. Cell therapy manufacturing flow chart.

(DSP) stages comprise microcarrier removal, where relevant, and volume reduction (VR) for concentration and washing of the cells. This is followed by formulation into the cryopreservation buffer, vial filling and cryopreservation.
Some cell therapy manufacturing processes include downstream processing and fill finish technologies that are not amenable to scale-up such as benchtop centrifuges for volume reduction and manual filling in laminar air flow cabinets. However, this quickly 
becomes impractical for large commercial lot sizes for some high dose, large commercial demand indications. There are a limited number of DSP technologies that have been purpose designed to meet the specific needs of allogeneic cell therapy manufacturing at large scale. These requirements include minimal processing time, achieving high concentration factors while preserving high cell viabilities, integrating volume reduction and washing to reduce impurity levels to $<1 \mathrm{ppm} \mathrm{[6]} \mathrm{and}$ providing a low-shear processing environment. Furthermore, technologies need to be closed, automated, scalable and employ single-use components; the latter of which has the added potential benefits of reducing turnaround time and cost of goods [7].

Early downstream processing efforts focused on adapting technologies utilized within the blood product processing industry to use single-use components for washing and concentration of cell therapy products at a small scale. Examples include the COBE 2991 (Terumo BCT, CA, USA) operating via density gradient centrifugation or Elutra Cell separation systems (Terumo BCT) which operate in fluidized bed centrifugation mode. However, the scale of these systems is a limitation as less than a liter can be processed per cycle. Other commercially available, continuous centrifugation-based systems such as the Carr Centritech Cell II or Unifuge allow for larger process volumes but may not easily integrate the washing step $[8]$. At commercial scales, handling harvest volumes of 100-1000s I per lot, it is necessary to consider more scalable technologies for volume reduction and washing. Hence this work focused on DSP technologies which were not only single-use, closed and automated but also scalable and with which experience in the commercial cell therapy industry was already available. These options include tangential flow filtration (TFF) and fluidized bed centrifugation (FBC). TFF is most commonly used in the protein or antibody industry for concentration or buffer exchange, and can also be optimized to work for cell therapy processes. During TFF, recirculation of the feed across the membrane surface minimizes filter fouling and also allows washing to be achieved when operated in diafiltration mode. Lonza (MD, USA) has optimized the TFF process set-up and operating conditions for both VR and washing of therapeutic cells (PCT Publication number WO2011091248 A1 [9]). The filter used is a hollow fiber filter. These filters generally possess a lower hold-up volume compared with flat sheet membrane cassettes and are available in ready-to-use presterilized formats by companies such as GE Healthcare $[8]$. Low shear, specifically a shear rate of less than $4000 \mathrm{~s}^{-1}$ (PCT publication number WO2011091248 A1 [9]), in these systems can be achieved by optimizing key process parameters such as the recirculation flow rate. Real-time monitoring of transmembrane pressure is also enabled by the incorporation of single-use pressure sensors. Gamma-irradiated bags, filters and tubing in addition to aseptic connectors such as GE Healthcare's Readymate ${ }^{\mathrm{TM}}$ connections and sterile tube welding reduce the risk of contamination.

FBC systems, such as the $\mathrm{kSep}^{\circledR}$ (KBI Biopharma, NC, USA), operate via counter-flow centrifugation, to provide a low shear environment for the cells. The opposing forces of fluid flow and centrifugal force result in the formation of a fluidized bed of cells, which allows for both volume reduction and washing, clearing residuals such as serum albumin from the media. These systems have a varying total single-use chamber capacity from $400 \mathrm{ml}$ to 61 [10] that can potentially handle 10-100s 1 from the expansion stage.

At small-scale, microcarrier beads are normally separated from cells by sieving post-trypsinization. At medium-to-large scale, systems to separate viable cells from microcarriers at larger volumes are under development. The difference in size and density between cells and microcarriers can be utilized for the separation of the latter using fluidized bed centrifugation such as kSep. Similarly, TFF using hollow fiber filters of the appropriate pore size can also be used for microcarrier removal. In addition, it would be advantageous to perform micro-

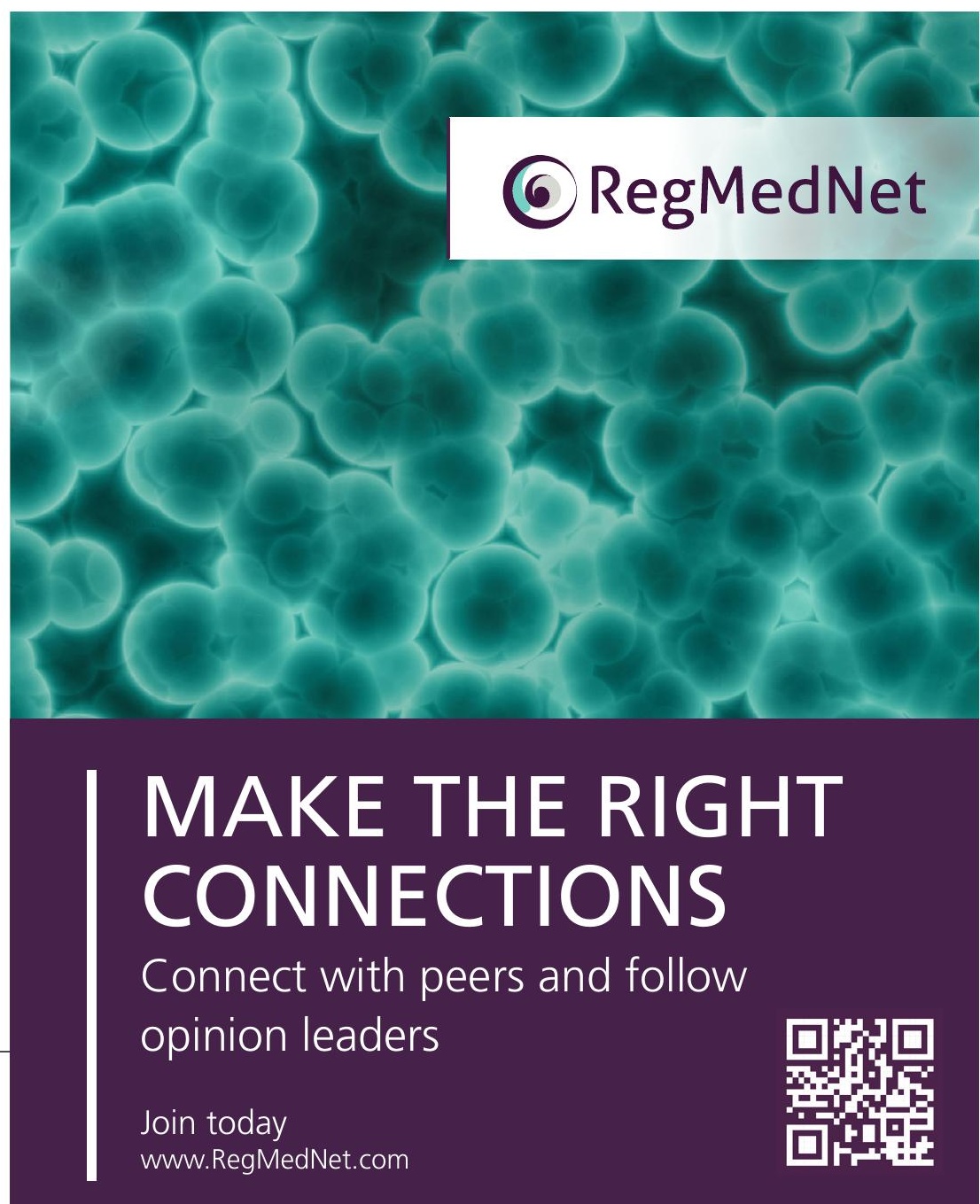




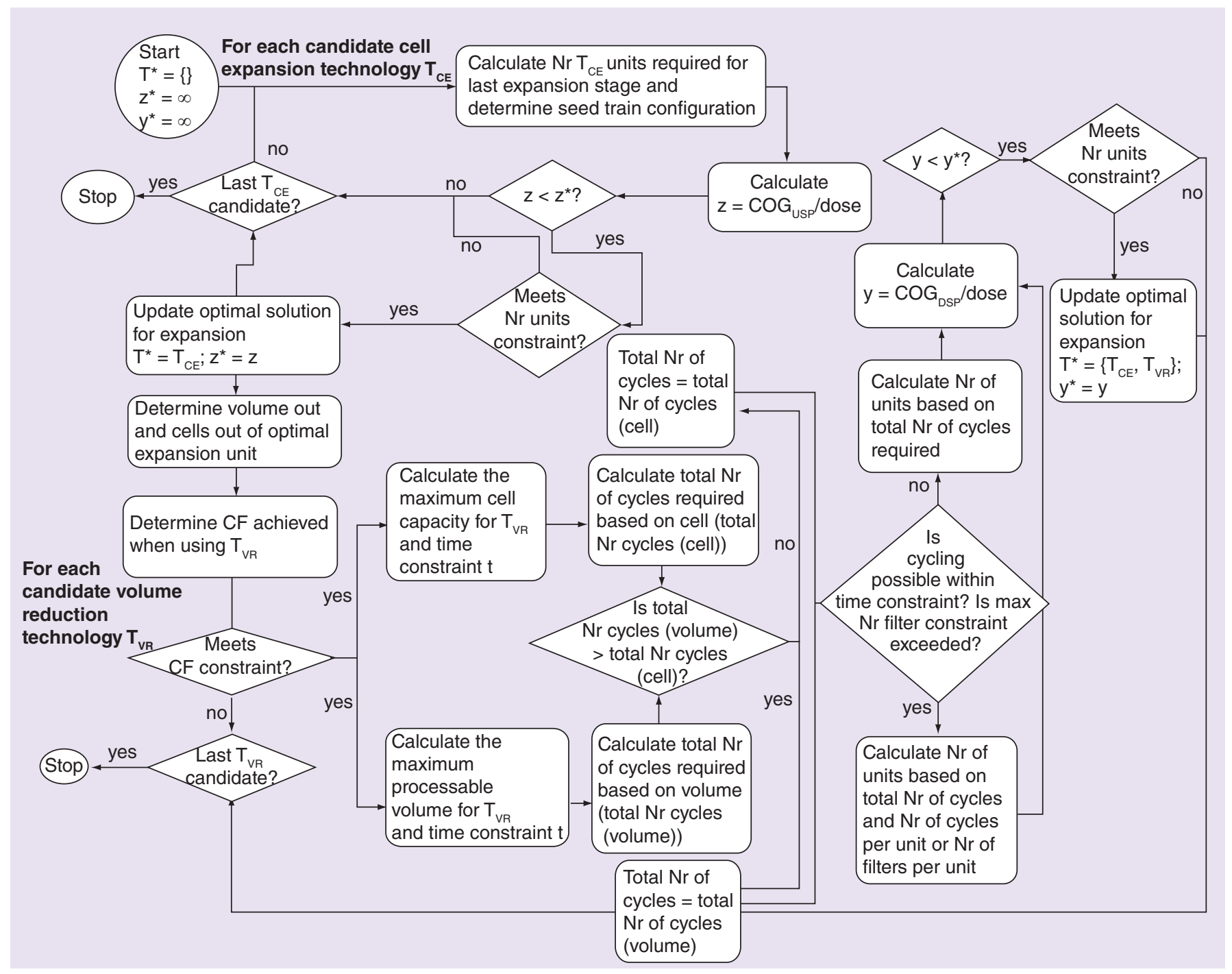

Figure 2. Cell expansion and volume reduction optimization framework.

CF: Concentration factor; Nr: Number.

carrier removal and VR and cell washing using the same technology so as to minimize losses between steps. More recently, alternative technologies for microcarrier separation are being developed, which include Pall Solohill's cell separation bag containing a $70 \mu \mathrm{m}$ screen and Thermoscientific's HyQ Harvestainer [11].

Since allogeneic cell therapies are most commonly stored in cryovials and cryopreserved, a range of automated vial filling machine scales were also investigated in this study. Following thawing of the cryopreserved product, in the clinic, the therapeutic cells should have a minimum viability of $70 \%$ (preferably more than $85 \%$ ), and a recovery of greater than $80 \%$ of viable cells [8] . A typical final product concentration is around 10 million cells $/ \mathrm{ml}$ (the focused target of this study) [8], with the majority of products in the 5 million cells $/ \mathrm{ml}$ to 25 million cells $/ \mathrm{ml}$ range, as required, for example, for aggravated rheumatoid arthritis or GvHD disease, respec- tively (clinical trials identifier: NCT01663116 [12], and identifier NCT00823316 [13], assuming administration of 4-20 ml and an average patient weight of $100 \mathrm{~kg}$ ). Vial filling at scale is likely to be carried out via largescale automated fill lines such as the Crystal ${ }^{\circledR}$ Px system from Aseptic Technologies. Cryo freezers for cell therapies allow for controlled-rate freezing and uniform freezing profiles, where cells are stored in the vapor phase of liquid nitrogen. This together with subsequent cold-chain management should enhance cell viability and quality for the product.

To date, published cost studies for cell therapy bioprocessing have focused solely on expansion options $[5,14]$. On the downstream front, Pattasseril et al. discussed the process limitations of traditional VR technologies used for cell therapy processing, and the potential capabilities of more scalable technologies that are being adapted for cell therapies [8]. However, there 
are no detailed cost studies published on downstream processing decisions for cell therapies. In this article, an integrated decisional tool incorporating bioprocess economics and optimization for addressing cell therapy downstream processing challenges is described. This article builds on the decisional tool described in [5] to capture the mass balances, equipment sizing, process economics and optimization algorithms for both the expansion and downstream processing stages of cell therapy bioprocesses. It describes the extension of the tool to model the distinctive features of each of the downstream processing stages so as to determine their cost-effectiveness for both planar and microcarrier-based flowsheets. The effect of scale and level of demand on optimal DSP technologies are investigated, highlighting the current technology limits and identifying where improvements in technologies are required to cope with larger future likely demands.

\section{Table 1. Key process and cost assumptions used in the case study.}

\begin{tabular}{|c|c|c|c|}
\hline Step & Vessel type & $\begin{array}{l}\text { Million cells } \\
\text { out/unit }\end{array}$ & Volume out (I) \\
\hline \multirow[t]{3}{*}{ Expansion } & L-10; L-40 & $159 ; 636$ & $0.48 ; 1.91$ \\
\hline & CL-12; CL-36; CL-120 & $150 ; 450 ; 1500$ & $0.40 ; 1.2 ; 3.6$ \\
\hline & MC-500; MC-1000; MC-2000 & $\begin{array}{l}173,053 ; 346,106 ; \\
692,213\end{array}$ & $375 ; 750 ; 1500$ \\
\hline Step & Process parameter & Value & \\
\hline \multirow[t]{4}{*}{ Microcarrier removal } & Step yield (\%) & 90 & \\
\hline & Number of microcarriers/g & $4.6 \times 10^{5}$ & \\
\hline & Diameter of a single microcarrier $(\mu \mathrm{m})$ & 150 & \\
\hline & Number of operators/unit & 2 & \\
\hline \multirow[t]{5}{*}{ Volume reduction } & Step yield (\%) & 85 & \\
\hline & Maximum time $(\mathrm{h})$ & 4 & \\
\hline & $\begin{array}{l}\text { Target final product concentration (in the vial; } \\
\text { million cells } / \mathrm{ml} \text { ) }\end{array}$ & 10 & \\
\hline & Number of washes in volume reduction step & 8 & \\
\hline & Number of operators/unit & 2 & \\
\hline \multirow[t]{5}{*}{ Cryopreservation and filling } & Step yield (\%) & 80 & \\
\hline & Maximum time $(h)$ & 2 & \\
\hline & Number of operators/unit & 2 & \\
\hline & Volume ratio of cells to DMSO & $1: 1$ & \\
\hline & Volume cryovial (ml) & 6 & \\
\hline Category & Cost parameter & Value & \\
\hline \multirow[t]{3}{*}{ Materials } & FBC single-use kit (FBC-A to FBC-B) & US $\$ 1800 / 4$ ch $(A)$, & $\$ \$ 8000 / 6 \mathrm{ch}(\mathrm{B})$ \\
\hline & TFF membrane (TFF-A to TFF-F) & $\begin{array}{l}\text { US\$1027 (A), US\$1 } \\
\text { (C), US\$2147 (D), } \\
\text { US\$3306 (F) }\end{array}$ & $\begin{array}{l}60 \text { (B), US\$1560 } \\
\$ 3306(E)\end{array}$ \\
\hline & Cryovial & US\$3/cryovial & \\
\hline \multirow[t]{5}{*}{ Other } & $\begin{array}{l}\text { QC (assumed split equally across expansion, volume } \\
\text { reduction and cryopreservation) }\end{array}$ & US $\$ 10,000 /$ lot & \\
\hline & Depreciation period (years) & 7 & \\
\hline & Lang factor & 23.67 & \\
\hline & Maintenance (\% FCl) & 10 & \\
\hline & Depreciation (\% FCI) & 7 & \\
\hline
\end{tabular}




\section{Table 2. Equations of the downstream processing model.}

$\mathrm{COG}_{\mathrm{DSP}} /$ dose

1

$$
\frac{\operatorname{COG}_{D S P}}{\text { dose }}=\frac{\sum_{j}\left(C_{\text {mat }, j}^{\text {anual }}+C_{l a b, j}^{\text {annual }}+C_{Q C, j}^{\text {annual }}+C_{C d p, j}^{\text {annual }}+C_{\text {maint }, j}^{\text {anual }}\right)}{D^{\text {annual }}}
$$

\section{Microcarrier removal with tangential flow filtration}

$V_{\text {fittrate }}=A_{i} F t_{\max }$

3

$V_{\text {max }}=V_{\text {fitrate }}+V_{M C}$

4

$C y_{\text {total }}=V_{\text {in }} / V_{\text {max }}$

$N_{\text {TFF }}=\frac{\left[V_{c y}\left(\frac{C y_{\text {total }}}{N_{\text {fiter }}}\right)\right]}{V_{\max }}$

6

$V_{\text {waste }}=\left(V_{\text {in per rig }}+V_{\text {prime per rig }}\right)-V_{\text {out per rig }}$

7

$C_{\text {Bag, Total }}=\left[\left(C_{\text {Bag, Vin per rig }}+C_{\text {Bag, Vuut per rig }}+C_{\text {Bag,waste }}+2 C_{\text {Bag,prime per rig }}\right) N_{T F F}\right]+C_{\text {Bag, Vout total }}$

8

$C_{\text {tubing, Total }}=\left(C_{\text {tubing, Feed }}+C_{\text {tubing,retentae }}+C_{\text {tubing,permeate }}\right) N_{T F F}$

9

$C_{\text {mat, } M C}^{\text {annual }}=\left(C_{\text {Baq, Total }}+C_{\text {prime }}+C_{\text {fitter }}+C_{\text {tubing,total }}\right) L_{\text {annual }}$

10

$C_{\text {lab }, M C}^{\text {annual }}=\left[\left(H t_{M C} O\right) N_{T F F}\right] L_{\text {annual }}$

Volume reduction with Tangential flow filtration

11

$C F_{\text {desired }}=\frac{2 X\left(V_{\text {in }}-V_{M C}\right)}{S_{\text {in }} Y_{V R} Y_{\text {cryo }}}$

12

$V_{\text {out }}=\frac{S_{\text {in }} Y_{\text {VR }} Y_{\text {cryo }}}{2 X}$

13

$V_{\max }=\frac{A_{i} F t_{\max }}{\left(1-\frac{1}{C F_{\text {actual }}}\right)+\left(\frac{N_{W}}{C F_{\text {actual }}}\right)}$

14

$C y_{\text {total,(cell) }}=\frac{V_{\text {in }}-V_{M C}}{V_{\max }}$

15

$C y_{\text {total, (volume) }}=\frac{S_{\text {in }}}{S_{M, i}}$

Largest $C y_{\text {total }}$ from 14 and 15 set to $C y_{\text {total }}$

16

$V_{D F}=\left(V_{\text {out per rig }} N_{W}\right)+V_{H F}+V_{H B}$

17

$V_{\text {waste }}=\left(V_{\text {in per rig }}+V_{\text {prime per rig }}+V_{D F}\right)-V_{\text {out per rig }}$

18

$t_{V R}=\frac{V_{\text {in per rig }}\left(\left(1-\frac{1}{C F_{\text {actual }}}\right)+\left(\frac{N_{w}}{C F_{\text {actual }}}\right)\right)}{A_{i} F}$

$C_{\text {mat, } \text { R }}^{\text {annual }}=\left(C_{\text {Bag, Total }}+C_{\text {prime }}+C_{\text {fitter }}+C_{\text {pump tubing,total }}+C_{\text {cflex tubing, total }}+C_{D F}\right) L_{\text {annual }}$

$C_{\text {equip, VR }}^{\text {annual }}=\left[\left(C_{\text {pump }}+C_{\text {lap }}+C_{F H}+C_{S B}+C_{\text {chil }}+C_{B H}+C_{B A}+C_{\text {skid }}+C_{\text {sens }}\right) N_{T F F}\right]+C_{\text {weld }}$ 
Table 2. Equations of the downstream processing model (cont.).

Microcarrier removal with fluidized bed centrifugation

21

$C F_{M C}=V_{\text {in }} / V_{\text {out }}$

22

$V_{\max }=\frac{\left(t_{\max }-t_{R}\right)}{\left(\frac{1}{Q_{S} N_{C h}}+\frac{1}{Q_{N} N_{c h}}+\frac{1}{C F_{M C} Q_{H} N_{c h}}\right)}$

23

$t_{M C \text { per cy }}=\frac{V_{\text {in per cy }}}{Q_{S} N_{c h}}+\frac{V_{\text {in per cy }}}{Q_{N} N_{c h}}+\frac{V_{\text {in percy }}}{C F_{M C} Q_{H} N_{c h}}+t_{R}$

24

$N_{F B C, M C}=\frac{V_{\text {in per cycle }} C y_{\text {total }}}{V_{\text {max }} N_{\text {cy per rig }}}$

25

$C_{\text {mat, } M C}^{\text {annual }}=C_{\text {Bag, Total }}+C_{\text {prime }}$

Cytotal estimated as in 14 and 15 above; labor cost estimated as in equation 10 with $\mathrm{N}_{\mathrm{FBC}}$.

Volume reduction with fluidized bed centrifugation:

26

27

$V_{\text {max }}=\frac{\left(t_{\text {max }}-t_{R}-\left(\frac{N_{w} V_{B}}{Q_{N}}\right)\right)}{\left(\frac{1}{Q_{S} N_{c h}}+\frac{1}{Q_{N} N_{c h}}+\frac{1}{C F_{M C} Q_{H} N_{c h}}\right)}$

28

$V_{\text {wash }}=\left(V_{\text {out per rig }} N_{w}\right)+V_{H B}$

$t_{V R}=N_{c y \text { per unit }}=\left(\frac{V_{\text {in per cy }}}{Q_{S} N_{c h}}+\frac{V_{\text {in percy }}}{Q_{N} N_{c h}}+\frac{V_{\text {in per cy }}}{C F_{\text {Desired }} Q_{H} N_{c h}}+t_{R}+\frac{N_{W} V_{B}}{Q_{N}}\right)$

29

$C_{\text {mat,VR }}^{\text {annual }}=\left(C_{\text {Bag, Total }}+C_{\text {cons }}+C_{\text {wash }}+C_{\text {prime }}\right) L_{\text {annual }}$

30

$C_{\text {equip, } V R}^{\text {annual }}=\left[\left(C_{F B C}+C_{\text {chil }}+C_{B H}+C_{\text {skid }}\right) N_{F B C}\right]+C_{\text {weld }}$

Vial filling precryopreservation

32

33

$t_{f}=\frac{N_{\text {cryo }}}{H_{\text {vial }}}$

$C_{\text {mat, } F}^{\text {annual }}=\left(C_{\text {form }}+C_{\text {vial }}\right) L_{\text {annual }}$

31

$C_{\text {lab, }, F}^{\text {annual }}=\left(H t_{f} O N_{f}\right) L_{\text {annual }}$

34

$C_{\text {equip }, F}^{\text {annual }}=C_{F M}+C_{F R}+C_{S B}$

\section{Materials \& methods}

Tool description

The decisional tool described in [5] was further developed to address the challenge of identifying the most cost-effective downstream processing and fill finish technologies and their sizes for cell therapies across a range of doses, demands and lot sizes. The model was created in C\# with the .NET framework (Microsoft1 Visual Studio 2010, Microsoft Corporation, WA, USA) linked to Microsoft ${ }^{\circledR}$ Access (Microsoft ${ }^{\circledR}$ Corporation, WA, USA). The DSP bioprocess economics model together with the input database was utilized to establish possible process flowsheets taking into account key process and technology-specific limitations, and calculations for resource consumption and equipment sizing. The flowsheets were then analyzed by the optimization algorithm (Figure 2) to establish the optimal process, with output results established in the database. Key input parameters for DSP, were the number of cells and total volume postexpansion and trypsinization; these are highlighted in Table 1. Once the optimal USP technology was fixed, the DSP cost of goods per dose $\left(\mathrm{COG}_{\mathrm{DSP}} /\right.$ dose $)$ was determined for a specific DSP flowsheet. For this analysis, the $\mathrm{COG}_{\mathrm{DSP}}$ /dose was determined by the sum of the annual direct operating costs (i.e., materials, labor and QC) and indirect costs (facility-dependent depreciation 
and maintenance costs) divided by the annual product output in number of doses/year (Equation 1 \& Table 2). The overall optimization framework is summarized in Figure 2. The key equations used in the model are summarized in Table 2 and the nomenclature is provided in the Supplementary Material (see online at www. futuremedicine.com/doi/full/10.2217/RME.15.29).

\section{Case study setup}

An industrially relevant case study was set up to investigate volume reduction (VR) and fill finish technologies for commercial allogeneic mesenchymal stromal cell (MSC) therapies. Volume reduction technologies investigated included tangential flow filtration of various filter and single-use set-up sizes, and fluidized bed centrifugation sizes of different total volume capacities. Table 1, and Supplementary Tables A1 \& A2 summarize the different volume reduction technologies evaluated in this study. A to $\mathrm{F}$ are used to distinguish between smallto-large TFF units, by varying six filter sizes for tangential flow filtration (TFF; from $0.023 \mathrm{~m}^{2}$ [denoted in this study as TFF-A] to $1.15 \mathrm{~m}^{2}$, [referred to as TFF-F]). Different volume capacities for fluidized bed centrifugation (FBC) were also investigated. In this article, $A$ and $B$ are used to distinguish between small and large units of fluidized bed centrifugation. FBC-A has a smaller total volume capacity than FBC-B, in other words, $1 \times 100$ $\mathrm{ml}$ chambers for FBC-A, (denoted as FBC-A [1ch]) to $4 \times 100 \mathrm{ml}$ chambers (referred to as FBC-A [4ch]) and $1 \times 1000 \mathrm{ml}$ chambers in FBC-B (i.e., FBC-B [1ch]) to $6 \times 1000 \mathrm{ml}$ chambers in FBC-B [6ch]. Vial filling technologies (denoted here as Fill; also highlighted in Supplementary Tables A1 \& A2), had varying vial filling capacities from $180 \times 1 \mathrm{ml}$ vials/h (referred to as Fill-A) to $10,800 \times 1 \mathrm{ml}$ vials $/ \mathrm{h}$ (denoted as Fill-D in this article). These tables were generated from literature sources and vendor communications, in addition to advice sought from industrial experts with respect to technology limits and process trade-offs. Examples of associated commercial names are in the footnotes or legends of Table 1 \& Supplementary Table A1. The tool was run for different scenarios to investigate the impact of different doses ranging from $10^{6}$ to $10^{9}$ cells/dose, annual demands of 1000-500,000 doses/year, and lot sizes (50-10,000 doses/lot), in order to identify optimal volume reduction and vial filling technologies at different doses, demands and lot size scenarios. Table 1, and Supplementary Tables A1 \& A2 highlight the key process and cost assumptions of the model.

Key model constraints included a limit of one equipment unit for volume reduction and washing per lot. This is a typical constraint in the well-established biopharmaceutical industry due to validation concerns. This is particularly important for cell therapy where time for cell concentration can be limited to $4-8 \mathrm{~h}$ [8] to maintain cell viability. For some cell types, tighter or more relaxed time constraints may be required. Another key model constraint was to determine whether the target final concentration at the end of the flowsheet could be reached, taking into account minimum harvest volumes for the VR technology. The time allowed for formulation and completion of vial filling precryopreservation was set to $2 \mathrm{~h}$ [8] because of the limited time cells can spend in cryopreservation medium at room temperature. This 2-h time-limit assumes the use of DMSO as a cryopreservation buffer, but could differ if a different cryopreservation medium was used.

\section{Results \& discussion}

Process limitations of downstream processing technologies for cell therapy

Figure 3A shows the maximum cell output attainable for planar and nonplanar expansion technologies considered in this article, when considering the maximum number of units that can possibly be handled in a single lot. The ideal number of volume reduction (VR) units was set to 1 , and this was dependent on several factors including maximum cell and volume capacity of the technology, target final concentration, time constraints for this process step, flux for TFF and operational flowrates for FBC. As each individual cell expansion unit such as T-flasks or Cell Factories produces a different number of cells per unit volume, the average, ( 0.36 billion cells/l) was used to evaluate TFF and FBC. As in [5], the expansion technologies were given abbreviations such as ' $\mathrm{L}$ ' to denote multilayer cell stacks or factories and 'cL' to denote compact multi-layer systems such as the Hyperstack (Corning, MA, USA). Figure 3A demonstrates that each expansion technology spans one log of performance in terms of billion cells per lot before being outperformed by a newer technology. For microcarrier-based singleuse bioreactors and the current performance in terms of cells per milliliter in culture (about 0.5 million cells $/ \mathrm{ml}$ ), two logs are attainable for single-use bioreactors (SUB) sizes spanning 20-2000 1; however, the maximum expected commercial lot size of $10^{13}$ cells is not attainable, as described in [5]. Under the VR technology and process conditions described in Table 1 and Supplementary Table A1, which includes a target concentration of 10 million cells $/ \mathrm{ml}$ and a constraint of 1 VR unit per lot, TFF can handle 3 billion cells (TFF-A with a $0.023 \mathrm{~m}^{2}$ membrane and smaller associated process lines) to 152 billion cells per lot (TFF-F with a $1.15 \mathrm{~m}^{2}$ membrane and larger associated process lines). Thus, for a target concentration of 10 million cells $/ \mathrm{ml}$, TFF is suitable for handling the maximum number of expansion units per lot for hollow fiber bioreactors, 

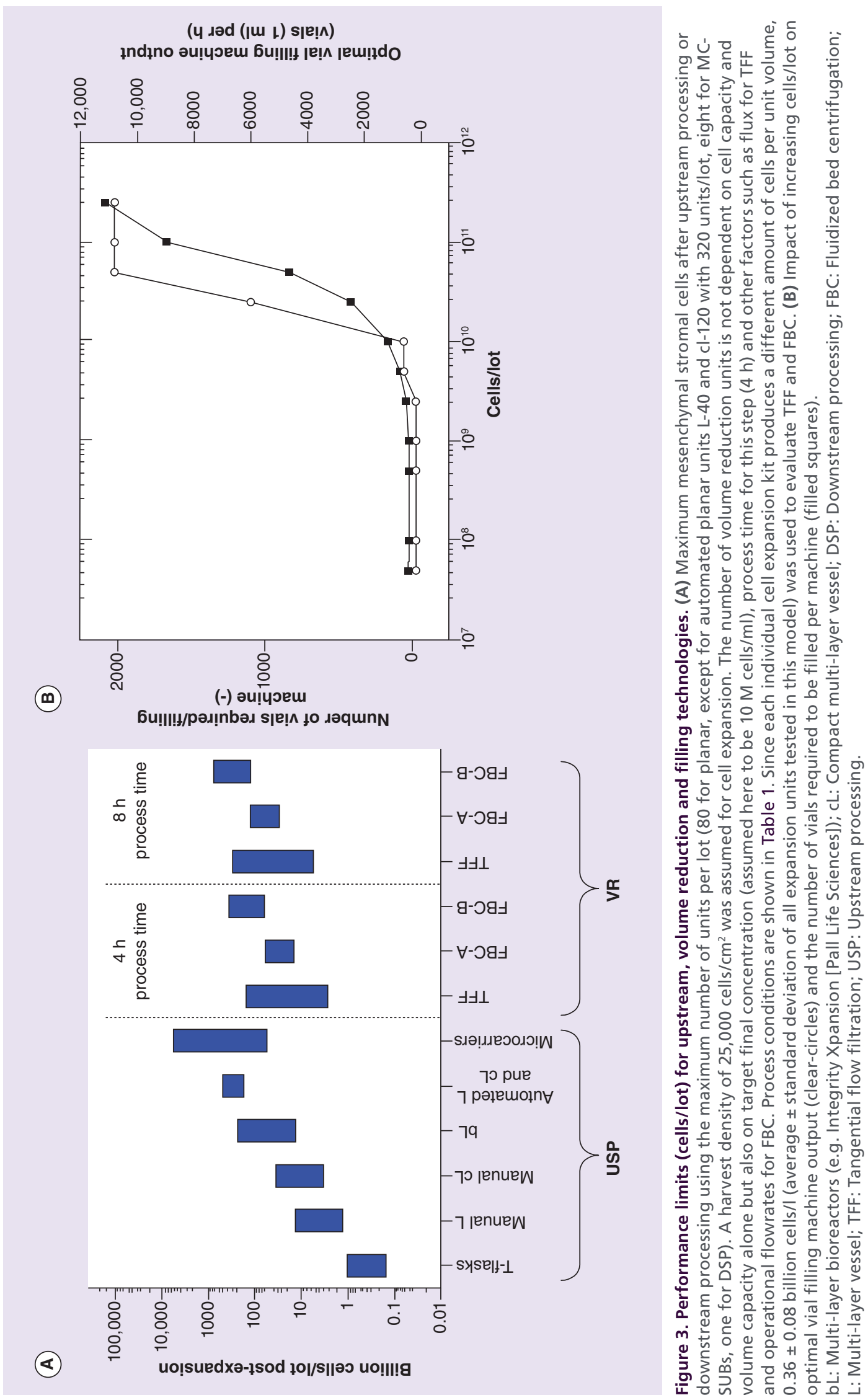
10-50 layer bioreactors, five- to ten-layer vessels and 12-36 layer compact vessels (note: automation allows a maximum of 320 vessels per lot). For smaller multilayer vessels, it is possible to use the smallest TFF, but the target final concentration would have to be lower than 10 million cells $/ \mathrm{ml}$. For automated planar vessels and microcarrier-based single-use bioreactors with a hypothetical pooled cell and volume load from eight $2000 \mathrm{l}$ bioreactors, it would also be possible to use TFF but more than one of the largest rigs (TFF-F) would be required to enable this. For FBC-A and FBC-B, the cell load limits per lot are $15-59 \times 10^{9}$ cells/lot and 60-222 × $10^{9}$ cells/lot, respectively. To enable FBC use for the maximum number of T-flasks, multi-layer vessels and smaller compact multi-layer vessels, the target final concentration would have to be lowered for FBC-A [1ch] to less than 10 million cells $/ \mathrm{ml}$, and for the maximum number of automated multi-layer and compact multi-layer vessels, and the pooled load of eight SUBs, FBC-B [6ch] can be used but more than one would be required per lot.

For the dose, demand and lot size scenarios tested in the model, the number of $6 \mathrm{ml}$ cryovials required per automated vial filling machine was plotted against cells per lot (Figure 3B). The number of cryovials required per optimal vial filling machine increased from 28 vials at 50 million cells per lot, to 2084 vials per vial filling machine at 250 billion cells per lot. The optimal vial filling machine capacities are plotted in the secondary axis of Figure 3B and have capabilities from $1801 \mathrm{ml}$ vials per hour (Fill-A) that are able to handle the lower cells per lot in the time constraint of $2 \mathrm{~h}$, to 10,800 vials per hour for the largest automated fill machine (Fill-D).

\section{Cost-effectiveness of downstream processing technologies for cell therapy}

Figure 4 addresses the overall optimal expansion, VR and vial filling technologies within the model's number of unit constraints for each step in the process. The expansion results are very similar to [5] where for expansion technologies the maximum number of planar expansion units that can be handled per lot is assumed to be 80 and the number of microcarrier-based SUBs is eight. The cell and volume outputs of optimal expansion technologies of Figure 4 are detailed in Table 1. In this study, however, the overall DSP yield was assumed to be $68 \%$, assuming an $85 \%$ VR yield and an $80 \%$ yield post thawing after cryopreservation. For processes including microcarrier-based SUBs, it was assumed that microcarrier removal resulted in a cell recovery of $90 \%$, and hence the overall DSP yield was $61 \%$. The optimal DSP technologies are based on optimal $\mathrm{COG}_{\mathrm{DSP}}$ /dose after finding the optimal USP technology based on $\mathrm{COG}_{\mathrm{USP}} / \mathrm{dose}$, in other words, for a fixed USP technol- ogy. This analysis considered typical commercial numbers of lots ranging from 10 to 200 lots per year. Each individual matrix cell shows the optimal technologies for a specific demand and lot size, in addition to the number of units required, indicated by square brackets. Facility depreciation was also taken into account in the indirect costs of this analysis, and so there is variation in optimal cell expansion technologies at each cells/lot compared to [5]. At lower lot sizes for a dose of $10^{6}$ cells, the demand is met by smaller expansion systems (Figure 4A). In these cases, TFF-A is the only option for cell washing and VR due to the lower minimum harvest volume allowed. In these cases however, the final possible cells per milliliter is also lower, in other words, $0.3-7$ million cells $/ \mathrm{ml}$. For the smaller lot sizes and doses shown in Figure 4A there may be a possibility in achieving 10 million cells $/ \mathrm{ml}$ if necessary instead of the lower targets theoretically achieved by the candidate technologies in our study using smaller systems used for concentrating lentiviral vectors, where it is possible to concentrate down to about $1 \mathrm{ml}$ [15]. This would increase the scope of TFF even further. At a dose of $10^{6}$ cells, a lot size of 2500 doses/lot, the optimal technologies that meet the maximum number of units constraints for each technology and can achieve the final desired 10 million cells $/ \mathrm{ml}$ and have the overall combined total COG/dose is $9 \mathrm{cl}-36$ units or $6 \mathrm{~L}-40$ units followed by FBC-A [1ch] and Fill-A because this is the only technology able to meet the target final concentration with one unit. Moving vertically down the matrix with increasing demand in doses/year, the difference in $\mathrm{COG}_{\mathrm{DSP}}$ /dose for alternate DSP technologies decreases. In situations where the COG/dose difference was less than $5 \%$, the model determined that either technology was feasible and this is shown for example at a dose of $10^{7}$ cells (Figure 4B), a lot size of 500 doses/lot and a demand of 100,000 doses/year where both TFF-C and FBC-A [1ch] are equally competitive.

In general, moving horizontally across the matrices solution space, as lot size increases, larger capacity VR technologies are required, for example, larger area TFF filter membranes or a greater number of chambers for FBC or volume per chamber, all necessary for maintaining the one unit DSP constraint. At a dose of $10^{7}$ cells per patient and a lot size of 10,000 doses/lot (Figure 4B), the largest unit of TFF (TFF-F) is the optimal VR technology able to achieve the target final concentration with a single unit and this is followed by Fill-C. Figure $4 \mathrm{C}$ shows that at a dose of $10^{8}$ cells and 2500 doses/lot, FBC-B is the clear winner as it is the only technology capable of meeting the number of units constraint of a single unit due to its larger cell and volume capacity. In our case study, filter areas of $0.023-1.15 \mathrm{~m}^{2}$ were investigated since these hollow 


\begin{tabular}{|c|c|c|c|c|c|c|c|c|c|c|c|c|c|}
\hline & $\begin{array}{c}\text { Final } \\
\text { cells } / \mathrm{ml}\end{array}$ & $0.3 \mathrm{M}$ & $0.7 \mathrm{M}$ & $3.5 \mathrm{M}$ & $7 \mathrm{M}$ & $10 \mathrm{M}$ & $10 \mathrm{M}$ & $3.5 \mathrm{M}$ & $7 \mathrm{M}$ & $10 \mathrm{M}$ & $10 \mathrm{M}$ & $10 \mathrm{M}$ & $10 \mathrm{M}$ \\
\hline & $\begin{array}{c}\text { Lot size } \\
\text { (doses/lot) }\end{array}$ & 50 & 100 & 500 & 1000 & 2500 & 10,000 & 50 & 100 & 500 & 1000 & 2500 & 10,000 \\
\hline \multirow{16}{*}{ 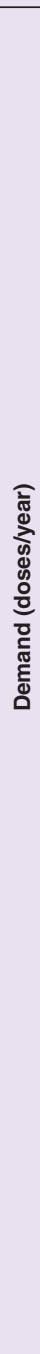 } & 1000 & $\begin{array}{c}\text { L-10 [1] } \\
\text { TFF-A } \\
\text { Fill-A }\end{array}$ & $\begin{array}{c}c L-12[1] \\
\text { TFF-A } \\
\text { Fill-A }\end{array}$ & & & \multirow{4}{*}{\multicolumn{2}{|c|}{$\begin{array}{l}c L-36[9] \\
F B C-A \\
\text { Fill-A }\end{array}$}} & $\begin{array}{c}\text { CL-36 [2] } \\
\text { TFF-A } \\
\text { Fill-A }\end{array}$ & $\begin{array}{c}c L-36[4] \\
\text { TFF-A } \\
\text { Fill-A }\end{array}$ & & & & \multirow[t]{4}{*}{ Dose $=10^{7}$} \\
\hline & 5000 & $\begin{array}{c}\text { L-10 [1] } \\
\text { TFF-A } \\
\text { Fill-A }\end{array}$ & $\begin{array}{l}\text { L-10 [1] } \\
\text { TFF-A } \\
\text { Fill-A }\end{array}$ & $\begin{array}{c}c L-36[2] \\
T F F-A \\
\text { Fill-A }\end{array}$ & & & & $\begin{array}{l}\text { CL-36 [2] } \\
\text { TFF-A } \\
\text { Fill-A }\end{array}$ & $\begin{array}{c}\text { CL-36 [4] } \\
\text { TFF-A } \\
\text { Fill-A }\end{array}$ & $\begin{array}{l}\text { CL-36 [17] } \\
\text { TFF-C } \\
\text { Fill-B }\end{array}$ & & & \\
\hline & 10,000 & $\begin{array}{l}\text { L-10 [1] } \\
\text { TFF-A } \\
\text { Fill-A }\end{array}$ & $\begin{array}{c}\text { L-10 [1] } \\
\text { TFF-A } \\
\text { Fill-A }\end{array}$ & $\begin{array}{l}\text { CL-36 [2] } \\
\text { TFF-A } \\
\text { Fill-A }\end{array}$ & $\begin{array}{c}C L-36[4] \\
\text { TFF-A } \\
\text { Fill-A }\end{array}$ & & & $\begin{array}{c}\text { CL-36 [2] } \\
\text { TFF-A } \\
\text { Fill-A }\end{array}$ & $\begin{array}{c}\text { CL-36 [4] } \\
\text { TFF-A } \\
\text { Fill-A }\end{array}$ & $\begin{array}{c}\text { CL-36 [17] } \\
\text { TFF-C } \\
\text { Fill-B }\end{array}$ & \begin{tabular}{|c|}
$C L-36[33]$ \\
TFF-D \\
Fill-B
\end{tabular} & & \\
\hline & 50,000 & & & $\begin{array}{l}\text { CL-36 [2] } \\
\text { TFF-A } \\
\text { Fill-A }\end{array}$ & $\begin{array}{l}\text { CL-36 [4] } \\
\text { TFF-A } \\
\text { Fill-A }\end{array}$ & & & & & $\begin{array}{c}\text { CL-120 [5] } \\
\text { TFF-C } \\
\text { Fill-B }\end{array}$ & $\begin{array}{l}\text { CL-120 [10] } \\
\text { TFF-D } \\
\text { Fill-B }\end{array}$ & $\begin{array}{l}\text { cL-120 [25] } \\
\text { TFF-D } \\
\text { Fill-C }\end{array}$ & \\
\hline & 100,000 & & & $\mathrm{cL}-36$ [2] & CL-36 [4] & cL-36 [9] & \begin{tabular}{|c|}
$c L-36[33]$ \\
\end{tabular} & & & \begin{tabular}{|l|}
$\mathrm{CL}-120[5]$ \\
\end{tabular} & $C L-120$ [10] & $\mathrm{CL}-120$ [25] & \begin{tabular}{|l} 
CL-120 [99] \\
\end{tabular} \\
\hline & & & & $\begin{array}{c}\text { TFF-A } \\
\text { Fill-A }\end{array}$ & $\begin{array}{c}\text { TFF-A } \\
\text { Fill-A }\end{array}$ & $\begin{array}{l}\text { FBC-A } \\
\text { Fill-A }\end{array}$ & $\begin{array}{c}\text { TFF-C } \\
\text { Fill-B }\end{array}$ & & & $\begin{array}{c}\text { TFF-C/FBC-A } \\
\text { Fill-B }\end{array}$ & $\begin{array}{c}\text { TFF-D } \\
\text { Fill-B }\end{array}$ & $\begin{array}{c}\text { TFF-D } \\
\text { Fill-C }\end{array}$ & $\begin{array}{l}\text { TFF-F } \\
\text { Fill-C }\end{array}$ \\
\hline & 500,000 & & & & & $\begin{array}{l}\text { L-40 [6] } \\
\text { FBC-A } \\
\text { Fill-A }\end{array}$ & $\begin{array}{c}C L-36[33] \\
\text { TFF-C } \\
\text { Fill-B }\end{array}$ & & & & & $\begin{array}{c}\text { cL-120 [25] } \\
\text { FBC-A } \\
\text { Fill-C }\end{array}$ & $\begin{array}{c}\text { CL-120[ 99] } \\
\text { TFF-F } \\
\text { Fill-C }\end{array}$ \\
\hline & $\begin{array}{c}\text { Final } \\
\text { cells/ml }\end{array}$ & $10 \mathrm{M}$ & $10 \mathrm{M}$ & $10 \mathrm{M}$ & $10 \mathrm{M}$ & $10 \mathrm{M}$ & $10 \mathrm{M}$ & $10 \mathrm{M}$ & $10 \mathrm{M}$ & $10 \mathrm{M}$ & $10 \mathrm{M}$ & $10 \mathrm{M}$ & $10 \mathrm{M}$ \\
\hline & $\begin{array}{c}\text { Lot size } \\
\text { (doses/lot) }\end{array}$ & 50 & 100 & 500 & 1000 & 2500 & 10,000 & 50 & 100 & 500 & 1000 & 2500 & 10,000 \\
\hline & 1000 & $\begin{array}{c}\text { cL-36 [17] } \\
\text { TFF-C } \\
\text { Fill-B }\end{array}$ & $\begin{array}{c}c L-36[33] \\
\text { TFF-D } \\
\text { Fill-B }\end{array}$ & & & & \multirow[t]{4}{*}{ Dose $=10^{8}$} & $\begin{array}{c}c L-120[50] \\
\text { TFF-F } \\
\text { Fill-D }\end{array}$ & $\begin{array}{c}\text { cL-120 [99] } \\
\text { TFF-F } \\
\text { Fill-D }\end{array}$ & & & \multirow{7}{*}{\multicolumn{2}{|c|}{ Dose $=10^{9}$}} \\
\hline & 5000 & $\begin{array}{c}\text { CL-120 [5] } \\
\text { TFF-C } \\
\text { Fill-B } \\
\end{array}$ & $\begin{array}{c}C L-120[10] \\
\text { TFF-D } \\
\text { Fill-B }\end{array}$ & \begin{tabular}{|c|} 
CL-120 [50] \\
TFF-F \\
Fill-D
\end{tabular} & & & & $\begin{array}{c}c L-120[50] \\
T F F-F / \\
F B C-A \text { Fill-D }\end{array}$ & $\begin{array}{c}\text { cL-120 [99] } \\
\text { TFF-F } \\
\text { Fill-D }\end{array}$ & & & & \\
\hline & 10,000 & CL-120 [5] & $c L-120$ [10] & CL-120 [50] & CL-120 [99] & & & $C L-120[50]$ & CL-120 [99] & & & & \\
\hline & & $\begin{array}{c}\text { TFF-C/ } \\
\text { FBC-A } \\
\text { Fill-B }\end{array}$ & $\begin{array}{c}\text { TFF-D } \\
\text { Fill-B }\end{array}$ & $\begin{array}{c}\text { TFF-F } \\
\text { Fill-D }\end{array}$ & $\begin{array}{c}\text { TFF-F } \\
\text { Fill-D }\end{array}$ & & & $\begin{array}{c}\text { TFF-FI } \\
\text { FBC-A } \\
\text { Fill-D }\end{array}$ & $\begin{array}{l}\text { TFF-F } \\
\text { Fill-D }\end{array}$ & & & & \\
\hline & 50,000 & & & $\begin{array}{c}c L-120[50] \\
T F F-F / \\
F B C-A \\
\text { Fill-D/C }\end{array}$ & $\begin{array}{c}\text { CL-120 [99] } \\
\text { TFF-F } \\
\text { Fill-D }\end{array}$ & \begin{tabular}{|c|} 
CL-120 [246] \\
FBC-B \\
Fill-D
\end{tabular} & & & & & & & \\
\hline & 100,000 & & & $\begin{array}{c}c L-120[50] \\
\text { TFF-FI } \\
\text { FBC-A } \\
\text { Fill-D/C }\end{array}$ & $\begin{array}{c}\text { CL-120 [99] } \\
\text { TFF-F } \\
\text { Fill-D }\end{array}$ & $\begin{array}{c}\text { CL-120 [246] } \\
\text { FBC-B } \\
\text { Fill-D }\end{array}$ & & & & & & & \\
\hline & 500,000 & & & & & $\begin{array}{c}c L-120[246] \\
F B C-B \\
F i l l-D[2]\end{array}$ & & & & & & & \\
\hline
\end{tabular}

Figure 4. Optimal upstream and downstream technologies for allogeneic cell therapy manufacture across varying dose, demand and lot size scenarios. Optimal cell expansion, volume reduction and vial filling technologies across a matrix of demands and lot sizes for a mesenchymal stromal cell dose of (A) $10^{6}$ cells, (B) $10^{7}$ cells (C) $10^{8}$ cells, (D) $10^{9}$ cells. For cell expansion technologies, there was a preference for planar technologies unless the maximum number of planar units per lot constraint was exceeded. Each matrix cell shows the name of the optimal technology for a particular combination of demand and lot size. The number of DSP units is 1 . The optimal option for each demand in terms of $\mathrm{COG}_{\mathrm{DSP}} /$ dose is highlighted in italics.

fiber systems are easily connected to sterile tubing and bags using GE Readymate ${ }^{\mathrm{TM}}$ sterile systems. However, filters of $2.6-11.3 \mathrm{~m}^{2}$ are also available in the market and can be provided in irradiated, sterile format in a 'module, bag, tubing' or MBT (KrosFlo ${ }^{\circledR}$ filters and $\mathrm{KrosFlo}^{\circledR}$ MAX filters from Spectrum Labs). All TFF units tested in the study feature as optimal solutions with the exception of intermediates, TFF-B and TFF-E, only due to the incremental changes in cells per lot that we investigated in this study. For FBC-A either using one chamber to four chambers are optimal with cycling for up to two cycles possible in some cases, for example, at a dose of $10^{8}$ cells, a demand of 50,000 doses per year and a lot size of 500 dose per lot. At a dose of $10^{9}$ cells, (Figure 4D) and a lot size of 500 doses per lot, in other words, $0.5 \times 10^{11}$ cells per lot, although the optimal cell expansion technology are $3 \times 1000$ lor $5 \times 5001$ microcarrier-based SUBs, none of the VR technologies are capable of meeting the one unit constraint as it would be necessary to use 3 units 
(A)

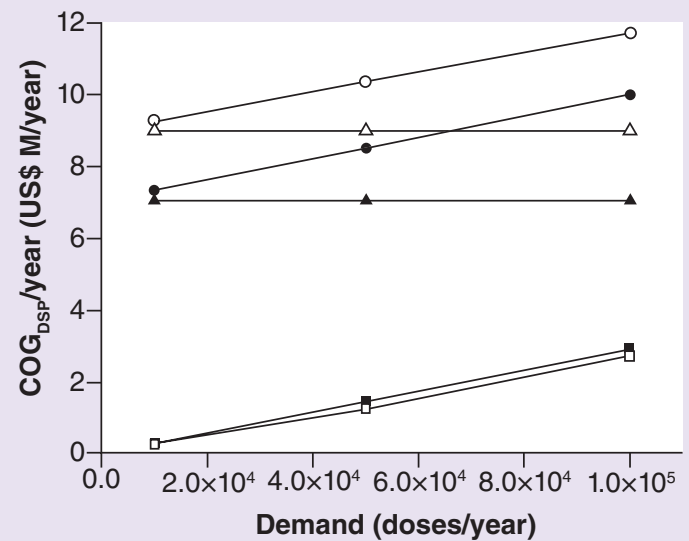

(B)

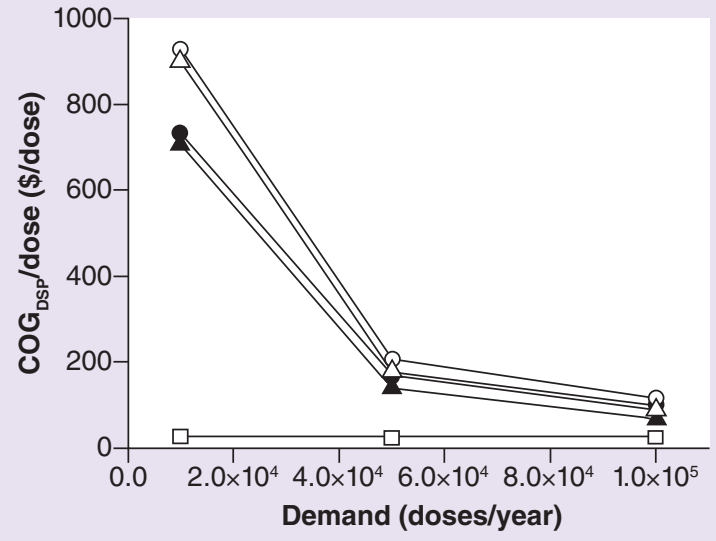

(C)

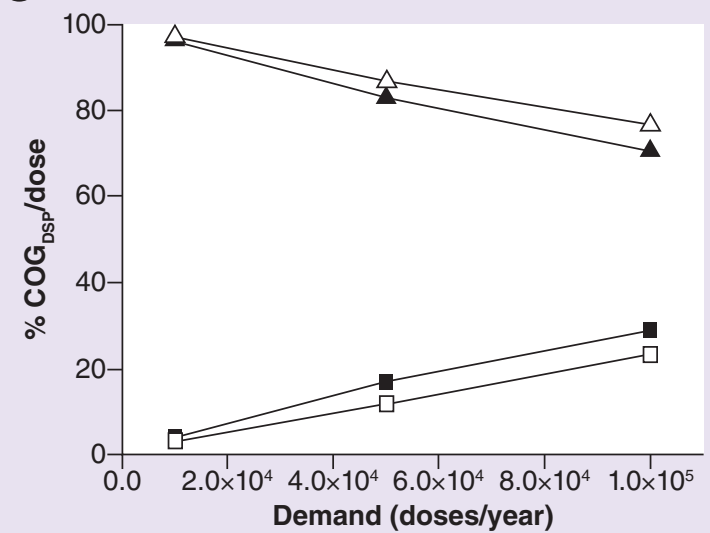

(D)

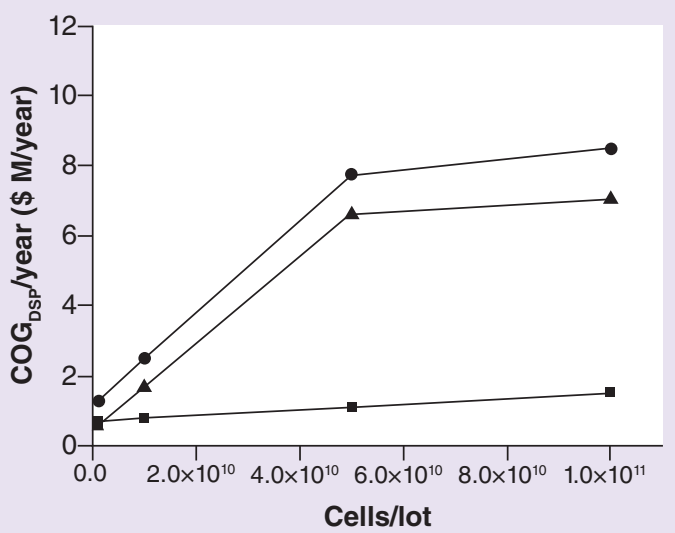

(E)

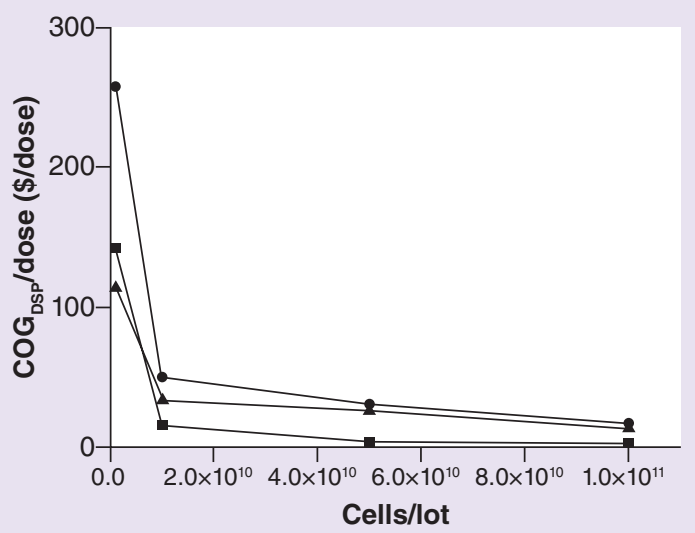

(F)

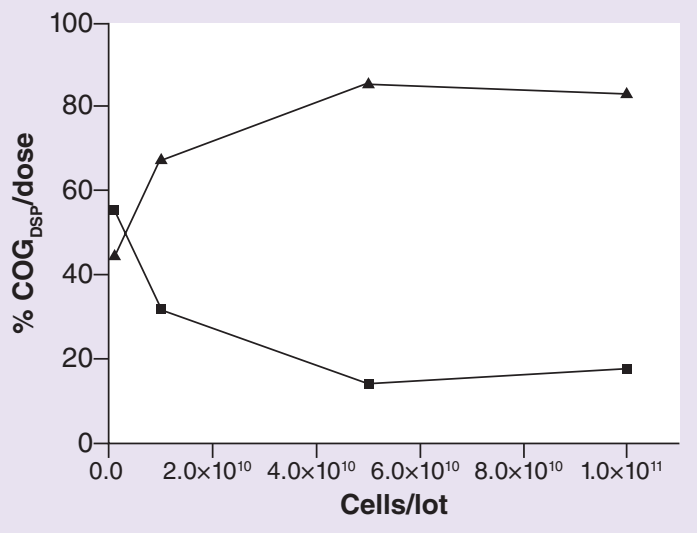

Figure 5. Economies of scale as a (A-C) function of demand and (D-F) cells per lot for (A \& D) COG ${ }_{D S P} /$ year, (B \& E) $C_{D G} /$ dose and (C \& F) \% COG ${ }_{D S P} /$ dose. The results are shown for 1 unit of FBC-B and 1 unit of TFF-F, both later filled using Fill-D. In (A-C), a single mesenchymal stromal cell dose of $10^{8}$ and a fixed lot size of 1000 doses per lot were assumed. For (D-F) a single mesenchymal stromal cell dose of $10^{7}$ was assumed with lot size and demand varying. Filled circles represent total costs for tangential flow filtration (TFF), clear circles are total costs for fluidized bed centrifugation (FBC), filled triangles are indirect costs for TFF, clear triangles are costs for $F B C$, filled squares are direct costs for TFF and clear squares are direct costs for FBC. Planar cell expansion in all cases.

of FBC-B with all six chambers to concentrate the pooled load from three SUBs within the 4-h time constraint, and this is represented by the light gray region in the matrix. Hence DSP bottlenecks are encountered before the USP bottleneck. The dark gray region at 10,000 doses per lot is due to both the cell expansion 
technologies and DSP technologies not being able to meet the maximum number of unit constraints.

The optimal technology at each demand and dose is highlighted in italics in Figure 4. At lower doses of number of cells per patient (e.g., $10^{6}$ cells), the optimal technology is more greatly influenced by the number of lots per year, such that direct costs decrease with decreasing number of lots, or increasing lot size and indirect costs are constant as there is no change in equipment. At the other end of the dose spectrum (e.g., $10^{9}$ cells), where the same DSP technology is used, indirect costs are similarly constant, but direct costs do not decrease in proportion with decreasing number of lots per year due to a need to process an increasing number of cells per lot causing an increasing direct cost for every lot.

\section{Key cost drivers for downstream processing technologies for cell therapy}

Figure $5 \mathrm{~A}-\mathrm{C}$ assess the economies of scale achieved by an increasing market demand in doses per year via a fixed facility outputting an increasing number of lots per year or an increasing cells per lot. The example shown here is for a dose of $10^{8}$ cells and a single lot size of 1000 doses per lot. Figure 5A is shown in $\mathrm{COG}_{\mathrm{DSP}}$ /year. As expected direct costs increase with dose output and indirect costs are fixed with increasing demand. These trends are similar for TFF and FBC. Figure 5B shows that direct $\mathrm{COG}_{\mathrm{DSP}} /$ dose for both technologies is constant. In contrast, the indirect $\mathrm{COG}_{\mathrm{DSP}} /$ dose decreases with demand, as these costs are spread over an increasing number of lots per year (at a fixed lot size), resulting in an overall decrease in $\mathrm{COG}_{\mathrm{DSP}} /$ dose due to economies of scale. As anticipated, the indirect $\mathrm{COG}_{\mathrm{DSP}} /$ dose represents a higher proportion of the total $\mathrm{COG}_{\mathrm{DSP}} /$ dose than the direct $\mathrm{COG}_{\mathrm{DSP}} /$ dose across all dose outputs, although the ratio of direct to indirect costs increases with demand for both technologies (Figure 5C). Figure 5D-F represent increasing cells per lot moving across a diagonal of the matrix at a dose of $10^{7}$ cells, for a fixed number of lots per year of 50 . Figure 5D \& E illustrates that as cells per lot increases (by increasing lot size or scale of production), both direct and indirect costs increase, but the relative increase in indirect costs is much higher as larger equipment is required as scale of production increases. As the cells per lot increases, the scale of production increases and larger equipment are used to produce a greater amount of cells per lot and hence total $\mathrm{COG}_{\mathrm{DSP}} /$ dose overall and both direct and indirect $\mathrm{COG}_{\mathrm{DSP}}$ /dose decrease (Figure 5E). Thus, for a constant number of lots per year, the proportion of $\mathrm{COG}_{\mathrm{DSP}} /$ dose represented by indirect costs increases and those represented by direct costs decrease (Figure 5F).
Figure $6 \mathrm{~A} \& \mathrm{~B}$ show a comparison of the cost breakdown for TFF and FBC for a fixed demand of 100,000 doses per year across different lot sizes (500 and 10,000 doses per lot) for a dose of $10^{7}$ cells/patient. Throughout, depreciation and maintenance dominate as FCI is considered as $23.67 \times$ the total equipment purchase cost, where 23.67 is the Lang factor previously established for disposable systems [16]. At 500 doses per lot, beyond depreciation, QC costs dominate, followed by material costs for TFF and FBC-A. Labor costs are the lowest contributor to overall costs in these cases. At 500 doses per lot, FBC-B cannot reach the target concentration factor of achieving 10 million cells per $\mathrm{ml}$ in the final vial due to its larger minimum harvest volume requirement brought about by its larger overall size and capacity, and hence it is not an option at this lot size. Overall, DSP technologies TFF-C with Fill-B and FBC-A [1ch] with Fill-B are optimal DSP technologies in terms of meeting the number of unit constraints and having the lowest $\mathrm{COG}_{\mathrm{DSP}}$ per dose for a fixed cell load of 181 of 7.5 billion cells from 5 cl-120 units. The difference in $\mathrm{COG}_{\mathrm{DSP}} /$ dose between both options is only $6 \%$. At 10,000 doses per lot, TFF-F followed by Fill-C is the optimal solution for $\mathrm{COG}_{\mathrm{DSP}} /$ dose (Figure $6 \mathrm{~B}$ ). At this lot size, depreciation is more significant due to the fact that there are fewer lots per year over which this depreciation can be spread. Since, FBC-A has a higher labor cost $(1.7 \times)$ and a slightly higher depreciation and maintenance $(1.2 \times$ greater $)$ than TFF, TFF-F followed by Fill-C has a $21 \%$ lower $\mathrm{COG}_{\mathrm{DSP}}$ /dose than FBC-A [4ch, 2cy] which also requires two FBC units and is hence optimal. Unlike at 500 doses per lot, at 10,000 doses per lot, FBC-B can reach the target concentration factor and hence is an option however, with Fill-C the overall $\mathrm{COG}_{\mathrm{DSP}} /$ dose is $26 \%$ higher than TFF with Fill-C. The detailed direct cost breakdown for TFF at 500 doses per lot and 10,000 doses per lot are shown in Figure 6C \& E. For FBC, Figure 6D \& F show that similar to $\mathrm{TFF}$, material costs are dominated by consumables rather than chemicals. On a per lot basis, QC costs dominate at 500 doses per lot whereas at 10,000 doses per lot, material costs are the main direct cost driver.

\section{Improvements required in current DSP technologies for future demands}

Figure 7A \& B analyzes debottlenecking strategies to address the gray region in Figure 4D where none of the candidate VR technologies are able to meet the number of unit constraints and assesses how the number of TFF-F and FBC-B units can be reduced to 1 unit. Figure 7A examines changing key VR parameters at a demand 50,000 doses per year and a lot size of 2500 doses per lot, and a dose of $10^{9}$ cells/patient, to achieve the desired 1 DSP unit per lot constraint. For TFF, 
(A)

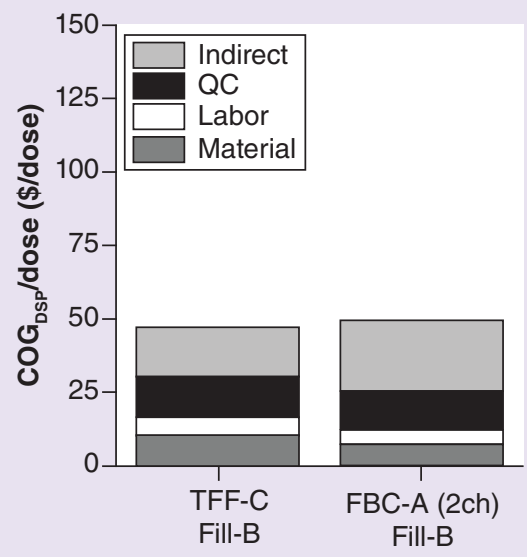

(C)

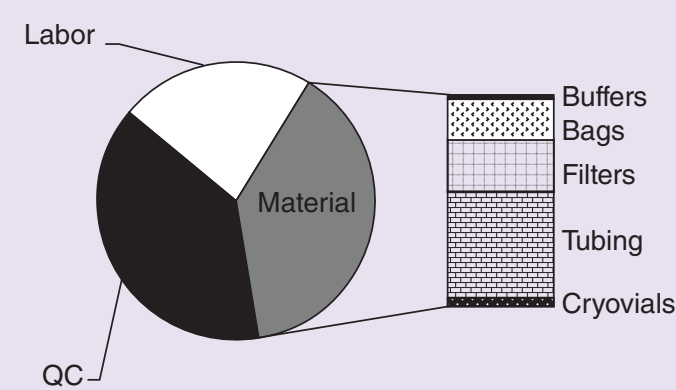

(E)

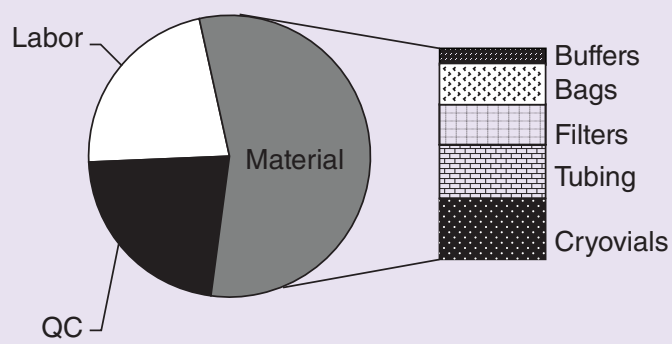

(B)

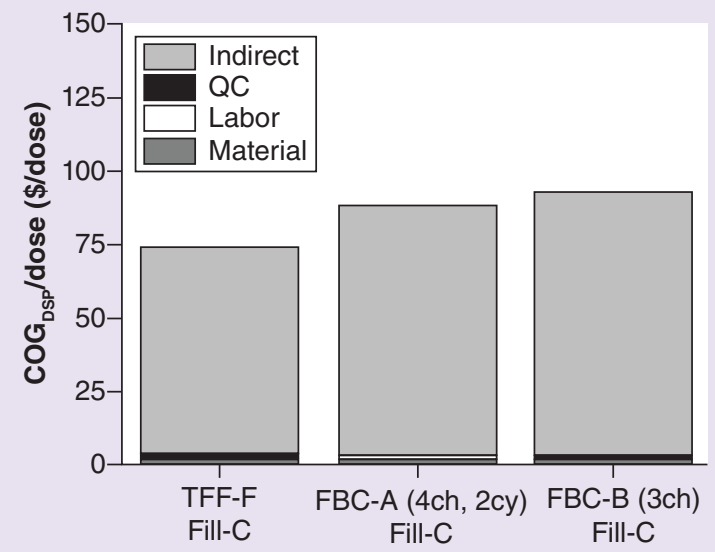

(D)

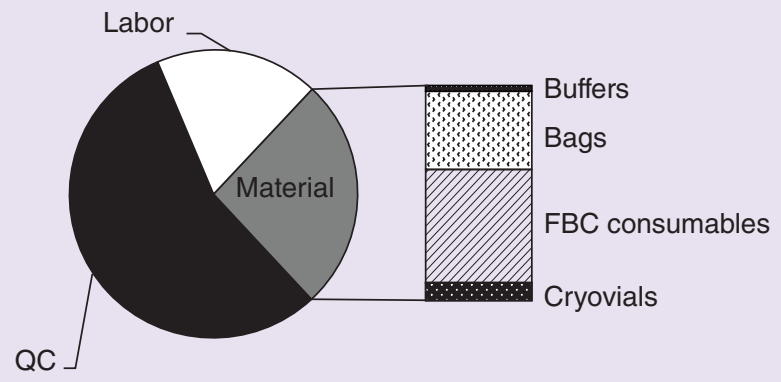

(F)

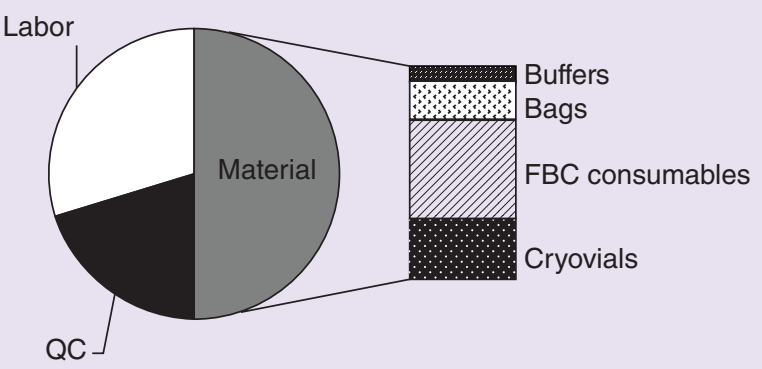

Figure 6. Cost breakdowns and drivers for $\mathrm{COG}_{\mathrm{DSP} P}$ dose. Comparison between TFF and FBC for a fixed demand of

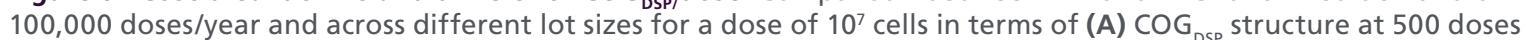
per lot and 200 lots per year (B) 10,000 doses per lot and ten lots per year. Detailed direct COG DSP $_{\text {b }}$ bakdown at 500 doses per lot for (C) TFF-C (D) FBC-A [2ch] both with Fill-B, and at 10,000 doses per lot (E) TFF-F (F) FBC-B [3ch] both with Fill-C.

FCB: Fluidized bed centrifugation; QC: Quality control; TFF: Tangential flow filtration.

the area of the bubbles represents the area of the filter membranes, whereas for FBC, the area of the bubbles represents the volume into the VR step. The base case is shown on the right hand side of the graph with a process time of $4 \mathrm{~h}$. With a $1.15 \mathrm{~m}^{2}$ membrane and a volume VR process time limitation of $4 \mathrm{~h}, 22$ TFF rigs are needed to process the pooled load from six 2000L
SUBs. For FBC processing this total load would require 9 FBC-B units. The left hand side of the graph has an increased process time constraint of $8 \mathrm{~h}$, and explores the use of future rigs able to accommodate 3 filters with filter cartridge areas that are up to four times larger than the current maximum. For example, using three $4.6 \mathrm{~m}^{2}$ membranes with this increased process time 
(A)

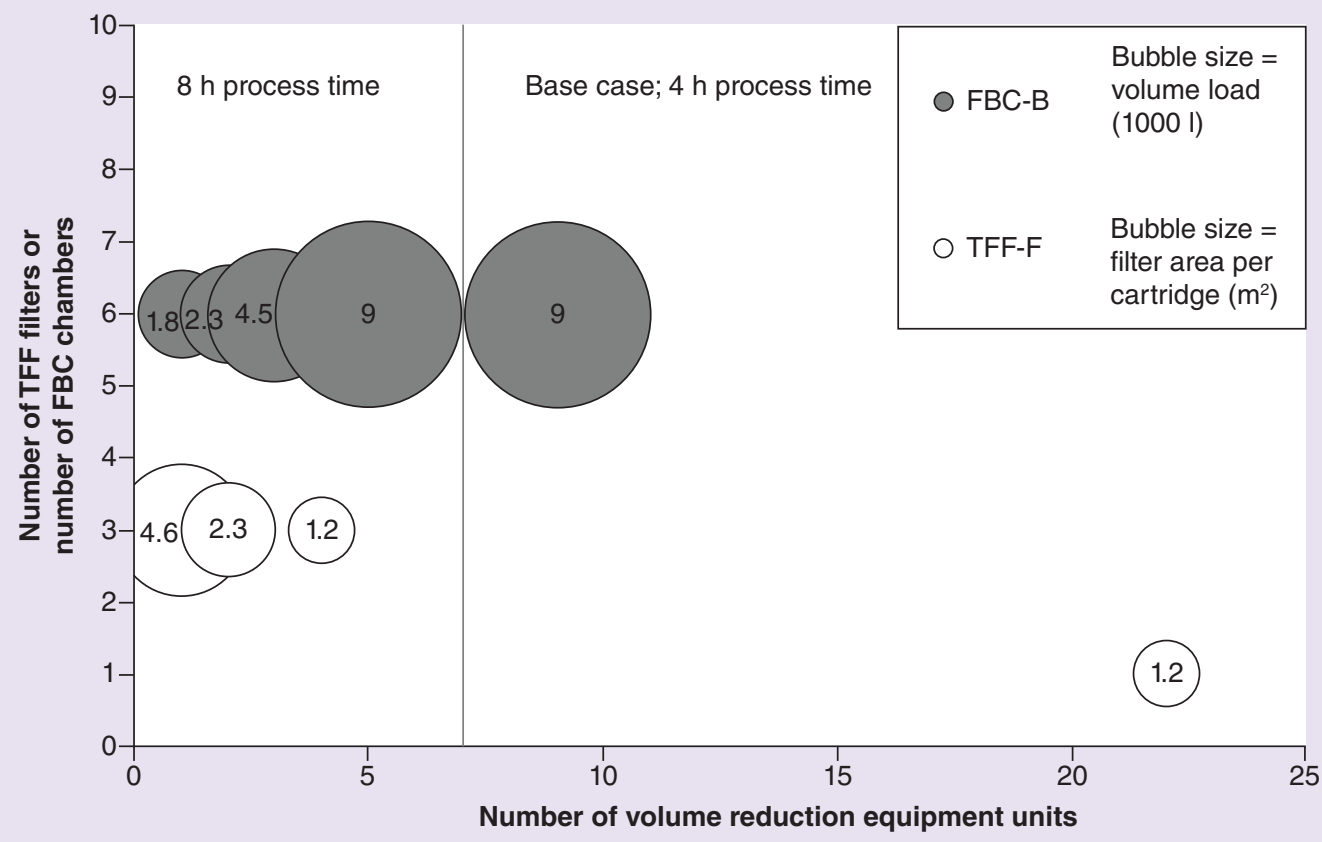

(B)

\begin{tabular}{|c|c|c|c|c|c|c|}
\hline \multirow{8}{*}{ 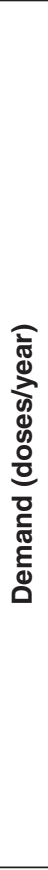 } & Dose & $10^{8}$ & $10^{9}$ & $10^{9}$ & $10^{9}$ & $10^{9}$ \\
\hline & $\begin{array}{l}\text { Lot size } \\
\text { (doses/lot) }\end{array}$ & 10,000 & 500 & 1000 & 2500 & 10,000 \\
\hline & 1000 & & & & & \\
\hline & 5000 & & $\begin{array}{l}\text { M-500 [5] } \\
\text { FBC-B } \\
\text { Fill-D [3] }\end{array}$ & & & \\
\hline & 10,000 & & $\begin{array}{c}\text { M-500 [5] } \\
\text { FBC-B } \\
\text { Fill-D [3] }\end{array}$ & $\begin{array}{c}\text { M-1000 [5] } \\
\text { TFF-F } \\
\text { Fill-D }\end{array}$ & & \\
\hline & 50,000 & & $\begin{array}{c}\text { M-500 [5] } \\
\text { FBC-B } \\
\text { Fill-D [3] }\end{array}$ & $\begin{array}{c}\text { M-1000 [5] } \\
\text { TFF-F } \\
\text { Fill-D }\end{array}$ & $\begin{array}{l}\text { M-2000 [6] } \\
\text { FBC-B } \\
\text { Fill-D [2] }\end{array}$ & \\
\hline & 100,000 & $\begin{array}{l}\text { M-1000 [5] } \\
\text { TFF-F } \\
\text { Fill-D }\end{array}$ & $\begin{array}{l}\text { M-500 [5] } \\
\text { FBC-B } \\
\text { Fill-D [3] }\end{array}$ & $\begin{array}{l}\text { M-1000 [5] } \\
\text { TFF-F/FBC-B } \\
\text { Fill-D }\end{array}$ & $\begin{array}{l}\text { M-2000 [6] } \\
\text { FBC-B } \\
\text { Fill-D [2] }\end{array}$ & \\
\hline & 500,000 & $\begin{array}{c}\text { M-1000 [5] } \\
\text { TFF-F/FBC-B } \\
\text { Fill-D }\end{array}$ & & & $\begin{array}{l}\text { M-2000 [6] } \\
\text { FBC-B } \\
\text { Fill-D [2] }\end{array}$ & \\
\hline & Strategy & $\begin{array}{c}\text { Staggered and } \\
8 \mathrm{~h}\end{array}$ & $\begin{array}{l}\text { Pooled } \\
\text { and } 8 \mathrm{~h}\end{array}$ & $\begin{array}{l}\text { Staggered } \\
\text { and } 8 \mathrm{~h}\end{array}$ & $\begin{array}{c}\text { Staggered } \\
\text { and } 8 \mathrm{~h}\end{array}$ & \\
\hline
\end{tabular}

Figure 7. Improvements required in current downstream processing technologies for future demands. (A) Bubble plot to depict the effect of changing a combination of process parameters to achieve an ideal of 1 downstream unit for a demand of 50,000 dose per year, a lot size of 2500 doses per lot and a dose of $10^{9}$. (B) Elimination of the light gray region in the matrices of Figure 5 and the impact of increasing process time to $8 \mathrm{~h}$ for volume reduction and/or staggering the load from bioreactors on optimal downstream processing technologies.

FCB: Fluidized bed centrifugation; TFF: Tangential flow filtration. 


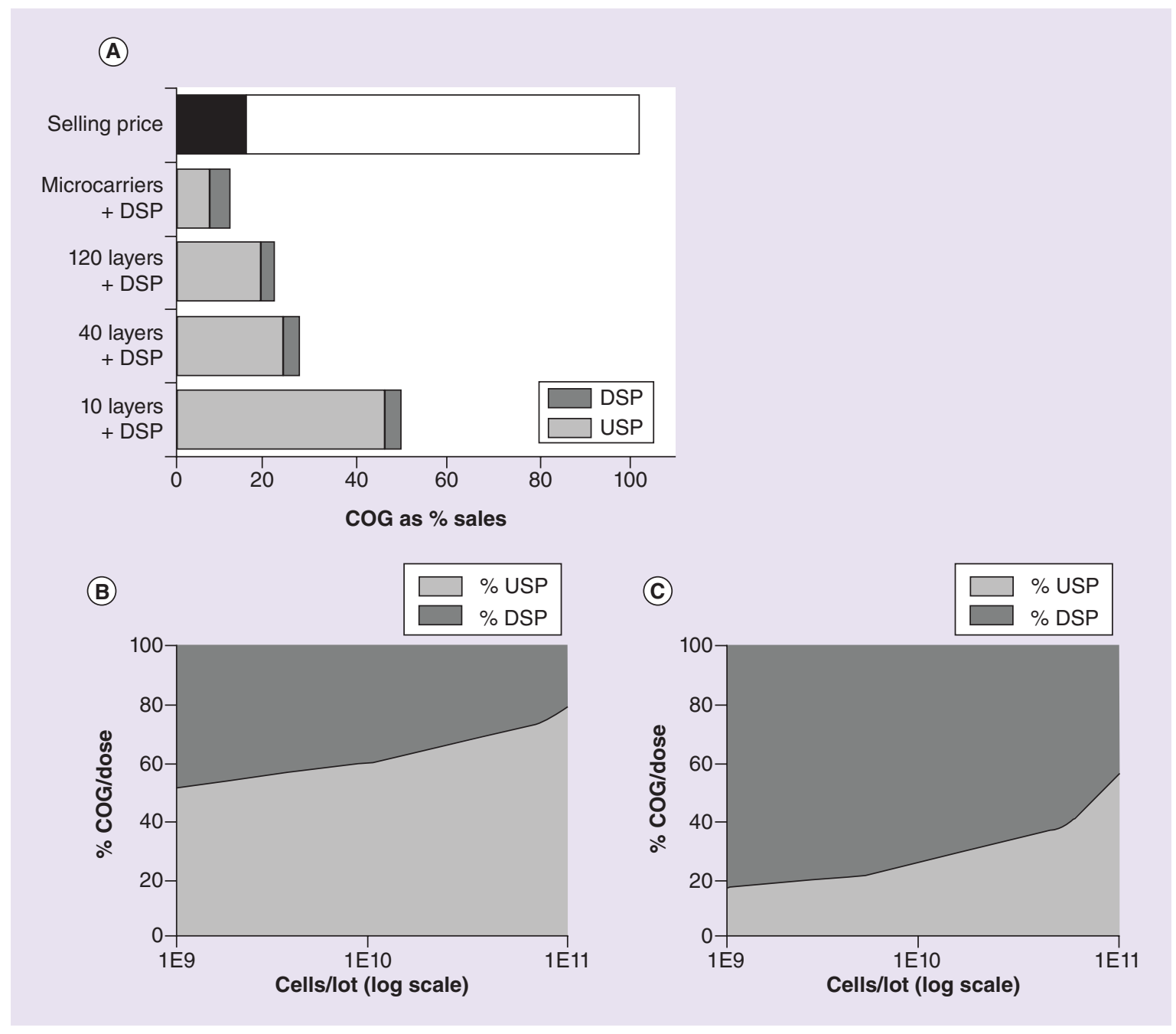

Figure 8. Target cost of goods and upstream to downstream COG ratios. (A) COG as a percentage of sales for a dose of a billion cells per patient, a demand of 10,000 doses per year and a lot size of 50 doses per lot for various cell expansion technologies. DSP is an average for tangential flow filtration and fluidized bed centrifugation followed by filling as these $C O G_{D S P}$ values were similar for this scenario. The black bar indicates a potential target value of $15 \%$ for COG as $\%$ sales. (B) Variation in the percentage of USP and DSP COG/dose as a function of increasing cells per lot for a planar cell expansion process and for a (C) microcarrier-based single-use bioreactor cell expansion process. The target final product concentration was lowered to enable the MC-SUB process to be feasible in C.

DSP: Downstream processing; USP: Upstream processing.

would allow TFF to be used. Alternatively, three $2.3 \mathrm{~m}^{2}$ filter cartridges at this increased process time, and half the load processed per unit time by staggered upstream processing (USP) would also give rise to 1 unit. Using the same principle for FBC, a fivefold decrease in cell load to $1.8 \mathrm{l}$ at the increased process time constraint of $8 \mathrm{~h}$ would also allow 1 DSP unit to be achieved.

Figure 7B shows how $1 \mathrm{VR}$ unit can be achieved in DSP for all gray regions in Figure 4D where the maximum number of SUBs per lot is not violated. This analysis shows that increasing the time allowed for this VR step to $8 \mathrm{~h}$ and/or staggering bioreactors allows 1 VR unit per lot to be achieved. At a dose of $10^{9}$ cells and 500 doses per lot, a pooled load from five $500 \mathrm{~L}$ bio- reactors can be handled by 1 FBC-B unit and 3 Fill-D units, in other words, a critical cells per lot input of 870 billion cells for a cell density load of 0.46 billion cells/l. Alternatively, if this load was to be staggered also, then a single FBC-B unit and 1 Fill-D unit would be possible. TFF can handle up to 152 billion cells which translate into processing up to $330 \mathrm{l}$ per unit in a 4-h window or 305 billion cells and $662 \mathrm{l}$ in an 8-h window. FBC can handle 346 billion cells and 7521 or 733 billion cells and 15931 in a 4 or 8 h, respectively with a single unit.

\section{Target cost of goods}

Figure 8A shows acceptable COG per dose for concentrating a cell load from planar vessels $(10,40$ or 120 layer 
vessels) and microcarrier-based SUBs at a dose of $10^{9}$ cells per patient, for a demand of 10,000 doses per year a lot size of 50 doses per lot. Regardless of the expansion technology, USP dominated the total COG, representing about $80 \%$ of the total COG/dose for this cells/lot value. A target COG as $\%$ sales value of $15 \%$ was chosen assuming allogeneic cell therapies will have gross margins in line with biologics to recover R\&D and sales and marketing costs with attractive profit margins [1]. Assuming reimbursement values and hence sales values could be in the order of US $\$ 40,000$, this would result in COG as percentage sales value of $21 \%$ for planar (i.e., US $\$ 8400 /$ dose) and $11 \%$ for microcarrier-based SUBs (i.e., US $\$ 4400 /$ dose). This analysis indicates that for this scenario, only MC-SUBs would be an acceptable option for this target COG as percentage sales.

\section{Upstream to downstream COG ratios}

The analysis explored whether COG values for allogeneic therapies are dominated by USP or DSP costs and how this is affected by increasing cells per lot for a planar and microcarrier-based SUB process. Figure 8B \& C shows that for both planar and MC-SUB technologies, as cells per lot increases, the proportion of $\mathrm{COG}_{\mathrm{USP}}$ increases and $\mathrm{COG}_{\mathrm{DSP}}$ decreases. Hence it is important to consider the cells per lot when determining $\mathrm{COG}_{\mathrm{USP}}$ : $\mathrm{COG}_{\mathrm{DSP}}$ ratios since they vary with scale. Figure $8 \mathrm{~B}$ shows that $\mathrm{COG}_{\mathrm{USP}}$ : $\mathrm{COG}_{\mathrm{DSP}}$ split is $45: 55$ at $10^{9}$ cells per lot to $80: 20$ at $10^{11}$ cells per lot. Since upstream production is cheaper for MC-SUBs, Figure $8 \mathrm{C}$ shows that at $1 \times 10^{9}$ cells $/$ lot $\mathrm{COG}_{\mathrm{USP}}: \mathrm{COG}_{\mathrm{DSP}}$ split is $20: 80$, but this shifts to $50: 50$ at $10^{11}$ cells/lot. The cost dis- tribution between USP and DSP for microcarrier-SUB processes is similar to the traditional biopharmaceutical industry where for recombinant protein production DSP normally represents $50-80 \%$ of the total COG [17]. Our analysis thus, highlights that the $\mathrm{COG}_{\mathrm{USP}}$ : $\mathrm{COG}_{\mathrm{DSP}}$ ratio depends on both the upstream route (planar vs microcarrier-SUB) and the desired cells/ lot and hence these factors must be considered when identifying where to focus process development efforts.

\section{Conclusion}

Deviations from the process platform investigated in this paper may occur in some cases and impact the economics of processes, such as: addition of an irradiation step in DSP for MSCs in order to preserve their immunosuppressive potential and inhibit their clonogeneic capacity [18]; the replacement of fetal bovine serum with human platelet lysate in cell culture and the subsequent impact on the DSP washing steps[19], and alterations to cryopreservation and thawing logistics following reports suggesting that there is reduced immunodulatory function of cryopreserved MSCs upon thawing $[19,20]$. Process economics analyses will help identify if these deviations have a significant impact on the overall economic feasibility of competing strategies.

\section{Future perspective}

Detailed process economics understanding as presented here provides visibility of the cost drivers, opportunities for cost reduction and allows the most promising strategies to be prioritized for further exploration. The upstream and downstream processing

\section{Executive summary}

A tool to identify the most cost-effective process flowsheets for allogeneic cell therapies

- A decisional tool to identify the most cost-effective process flowsheets for allogeneic cell therapies (mesenchymal stromal cells) across a range of production scales was developed.

- Bioprocess economics was integrated with optimization to assess the competitiveness of cell expansion technologies (i.e., planar or bioreactor) and single-use and scalable volume reduction technologies (VR).

Volume reduction technologies \& downstream processing

- The tool predicted that tangential flow filtration was generally more cost effective for the lower cells per lot obtained in planar technologies and that fluidized bed centrifugation became the only feasible option for handling large bioreactor outputs.

- Commercial lot sizes greater than 500 billion cells per lot required multiple large bioreactors and was found to lead to VR bottlenecks.

- Debottlenecking strategies explored included staggering bioreactors and doubling the time constraint for VR.

- Downstream processing contribution to the COG per dose was found to be more significant at smaller scales with observed ranges of $20-55 \%$ using planar upstream technologies, and $50-80 \%$ using bioreactors.

Conclusion

- For lower cells per lot achieved in planar technologies, tangential flow filtration was the more cost-effective option.

- For higher cells per lot achieved in large single-use bioreactors, fluidized bed centrifugation became the only feasible option.

- Only bioreactor-based flowsheets coupled with either filtration or centrifugation would allow for a successful business model for high-dose scenarios. 
bottlenecks identified highlight the technical innovation and optimization required to adapt existing technologies for cell therapies so as to bridge the gaps constraining large-scale production. The sector's progress is indicative that it will be able to move toward higher yielding, more robust and scalable manufacturing processes and that this will result in more cost-effective production of allogeneic cell therapies and hence feasible business models. Yet the benefits of early identification of cost effective and scalable manufacturing processes could be critical to achieving a sustainable business model. Companies face challenges handling commercial demands that require a switch in manufacturing technologies especially since cell characterization assays may make comparability difficult. Thus the cell therapy community and evolving development and regulatory pathway for mesenchymal stromal cells have an important role to play in the future economics for allogeneic cell therapy manufacturing.

A future paper from the authors will present an analysis of the consequences of process changes preand post-approval not only on cost of goods but also on the cost and time of drug development as well as the overall profitability over a drug's path to market.

\section{Acknowledgments}

Constructive feedback and technical advice from industrial experts at Lonza, kSep Systems, GE Healthcare, Spectrum Labs and Aseptic technologies is gratefully acknowledged. UCL

\section{References}

1 Smith DM. Assessing commercial opportunities for autologous and allogeneic cell-based products. Regen. Med. 7, 721-732 (2012).

2 Brandenberger R, Burger S, Campbell A, Fong T, Lapinskas E, Rowley JA. Cell therapy bioprocessing. BioProcess Int. 9(Suppl. 1), 30-37 (2011).

3 Kirouac DC, Zandstra PW. The systematic production of cells for cell therapies. Cell Stem Cell 3, 369-381 (2008).

4 Rowley J, Abraham E, Campbell A, Brandwein H, Oh S. Meeting lot-size challenges of manufacturing adherent cells for therapy. BioProcess Int. 10, 16-22 (2012).

5 Simaria AS, Hassan S, Varadaraju $\mathrm{H}$ et al. Allogeneic cell therapy bioprocess economics and optimization: single-use cell expansion technologies. Biotechnol. Bioeng. 111(1), 69-83 (2014).

6 US FDA. 21 CFR 610.15. Code of Federal Regulations, general biological products standards, constituent materials. www.accessdata.fda.gov/scripts/cdrh

7 Farid SS, Washbrook J, Titchener-Hooker NJ. Decision support tool for assessing biopharmaceutical strategies under uncertainty: stainless steel vs. disposable equipment for clinical trial material preparation. Biotechnol. Progr. 21, 486-497 (2005). hosts the EPSRC Centre for Innovative Manufacturing in Emergent Macromolecular Therapies with Imperial College and a consortium of industrial and government users.

\section{Financial \& competing interests disclosure}

Financial support was received from the Technology Strategy Board (UK) and Lonza is gratefully acknowledged. The research itself was part of a large TSB project and TSB had arranged for EPSRC to fund the UCL component. The authors have no other relevant affiliations or financial involvement with any organization or entity with a financial interest in or financial conflict with the subject matter or materials discussed in the manuscript apart from those disclosed

No writing assistance was utilized in the production of this manuscript.

\section{Ethical conduct of research}

The authors state that they have obtained appropriate institutional review board approval or have followed the principles outlined in the Declaration of Helsinki for all human or animal experimental investigations. In addition, for investigations involving human subjects, informed consent has been obtained from the participants involved.

\section{Open access}

This work is licensed under the Creative Commons Attribution 4.0 License. To view a copy of this license, visit http://creativecommons.org/licenses/by/4.0/

8 Pattasseril J, Varadaraju H, Lock LT, Rowley JA. Downstream technology landscape for large-scale therapeutic cell processing. Bioprocess Int. 11(3), 38-47 (2013).

9 Rowley J, Pattasseril J, Mohamed A. High yield method and apparatus for volume reduction and washing of therapeutic cells using tangential flow filtration. WO 2011091248 A1. (2011)

10 Ksepsytsems. www.ksepsytsems.com

11 Szczypka M, Splan D, Woolls H, Brandwein H. Singleuse bioreactors and microcarriers scalable technology for cell-based therapies. Bioprocess Int. 12(3), 54-64 (2014).

12 ClinicalTrials Database: NCT01663116. https://clinicaltrials.gov/ct2/show/NCT01663116

13 ClinicalTrials Database: NCT00823316. https://clinicaltrials.gov/ct2/show/NCT00823316

14 Malik N . Allogeneic versus autologous stem-cell therapy. Biopharm Int. 25(7), 36-40 (2012).

15 Cooper AR, Patel S, Senadheera S, Plath K, Kohn DB, Hollis RP. Highly efficient large-scale lentiviral vector concentration by tandem tangential flow filtration. J. Virol. Methods 177 1-9 (2011)).

16 Pollock J, Ho SV, Farid SS. Fed-batch and perfusion culture processes: economic, environmental, and operational 
feasibility under uncertainty, Biotech Bioeng 110, (1) 206-219 (2013).

17 Lowe CR, Lowe AR, Gupta G et al. New developments in affinity chromatography with potential application in the production of biopharmaceuticals. J. Biochem. Biophys. Methods 49, 561-574 (2001).

18 Andrade AVG, Riewaldt J, Wehner R et al. Gamma irradiation preserves immunosuppressive potential and inhibits clonogenic capacity of human bone marrowderived mesenchymal stromal cells. J. Cell Mol. Med. 18(6), 1184-1193 (2014).
19 Wuchter P, Bieback K, Schrezenmeier H, et al. Standardization of Good Manufacturing Practicecompliantproduction of bone marrow-derived human mesenchymal stromal cells forimmunotherapeutic applications. Cytotherapy 17(2), 128-139 (2015).

20 Francois M, Copland IB, Yuan S, et al. Cryopreserved mesenchymal stromal cells display impaired immunosuppressive properties as a result of heat-shock response and impaired interferon gamma licensing. Cytotherapy 14, 147-152 (2012). 